\title{
Physicochemical Properties and Microbiological Quality of ititu (Traditionally Fermented Cow Milk) in Selected District of Borena Zone, Oromia Regional State, Ethiopia
}

\author{
Beshir Hussien1, Yonas Hailu², Mitiku Eshetu² \\ ${ }^{1}$ Oromia Agricultural Research Institute, Yabello Pastoral and Dryland Agriculture Research Center, Yabello, Ethiopia \\ ${ }^{2}$ School of Animal and Range Sciences, Haramaya University, Dire Dawa, Ethiopia \\ Email: beshirhussein02@gmail.com
}

How to cite this paper: Hussien, B., Hailu, Y. and Eshetu, M. (2021) Physicochemical Properties and Microbiological Quality of ititu (Traditionally Fermented Cow Milk) in Selected District of Borena Zone, Oromia Regional State, Ethiopia. Open Journal of Animal Sciences, 11, 125-138.

https://doi.org/10.4236/ojas.2021.112010

Received: November 13, 2020

Accepted: April 5, 2021

Published: April 8, 2021

Copyright $\odot 2021$ by author(s) and Scientific Research Publishing Inc. This work is licensed under the Creative Commons Attribution International License (CC BY 4.0).

http://creativecommons.org/licenses/by/4.0/

(c) (i) Open Access

\begin{abstract}
The study was conducted to investigate the physicochemical properties and microbial quality of ititu produced in the Borana zone. A total number of 35 ititu samples, 30 traditionally made plus 5 laboratories made ititu, were analyzed for their physicochemical properties and microbiological quality. The overall average $( \pm \mathrm{SD})$ values for $\mathrm{pH}$, titratable acidity, total protein, fat, total solids, and ash were $3.59 \% \pm 0.04 \%, 2.86 \% \pm 0.18 \%, 7.26 \% \pm 0.41 \%, 9.85 \% \pm$ $0.73 \%, 21.23 \% \pm 1.48 \%$, and $0.84 \% \pm 0.11 \%$, respectively for traditionally made ititu. The result of all physicochemical parameters of traditional ititu was not significantly) different $(\mathrm{P}>0.05)$ with laboratory-made ititu (control sample). The average $( \pm \mathrm{SD})$ total bacteria count $(\mathrm{TBC})$, coliform count (CC), yeast and mould count (YMC), Staphylococcus aureus count and Listeria monocytogenes count were $8.36 \pm 1.29,3.47 \pm 0.51,8.06 \pm 1.28,3.79 \pm 0.91$ and $3.15 \pm 0.17 \log _{10} \mathrm{cfu} / \mathrm{ml}$, respectively for traditional ititu. Whereas, the corresponding values for the laboratory-made ititu were $4.17 \pm 0.55 \log _{10} \mathrm{cfu} / \mathrm{ml}$, $0,5.76 \pm 0.57 \log _{10} \mathrm{cfu} / \mathrm{ml}, 0$ and 0 , respectively. Significant $(\mathrm{P}<0.05)$ differences were observed between traditional and laboratory-made ititu for coliform, S. aureus and L. monocytogenes count. The Prevalence of pathogenic microorganisms for S. aureus and L. monocytogenes were $33.33 \%$ and $6.67 \%$, respectively for traditionally made ititu while not detected for laboratory-made ititu. The results indicated that the quality of traditional ititu was substandard and not safe for consumption. This in general, the production of ititu in the study area requires intervention such as awareness creation of keeping good hygienic quality and pasteurization (heating up to boiling) of milk to be used for ititu making in order to make it safe from the public
\end{abstract}


health point of view.

\section{Keywords}

ititu, Cow, Fermented Milk, Microbiology, Physicochemistry

\section{Introduction}

Livestock represents major national resources and forms an integral part of the agricultural production system in the country [1]. Ethiopia is one of the developing countries in which urban and peri-urban dairying constitutes an important sector of the agricultural production system [2]. Milk is considered one of the most important diet items of many people and is nutritionally defined as the most nearly "perfect food" which is a compensatory part of daily diet especially for the expectant mothers as well as growing children [3]. Milk production systems can be broadly categorized into urban, peri-urban and rural milk production systems [4]. The rural dairy system is part of the subsistence farming system that contributes up to $98 \%$ of the total milk production in Ethiopia and includes pastoralists, agro-pastoralists, and mixed crop-livestock producers [5] [6] and [7]. In Ethiopia, consumption of raw milk and milk products is common that may lead to the transmission of various diseases and has public health hazards [8] [9] Apart from the quality and safety concerns, poor handling practices in the country causes postharvest losses [9] [10].

Traditional fermented milk products are widely consumed in the entire world. These products are an important supplement to the local diet and provide vital elements for growth, good health [11] [12] and an appreciated flavor. Microorganisms of lactic acid starter cultures used for the conversion and preservation of milk products are unique bio-converters of energy. In the earlier days, fermentation was used to control the growth of harmful bacteria and some pathogens, while making indigenous milk products. The microorganisms principally encountered in the dairy industry are bacteria, yeasts, molds and viruses. Some of the bacteria (lactic acid bacteria) are useful in milk processing, causing milk to sour naturally. However, milk can also contain pathogenic bacteria, such as Salmonella spp., Staphylococcus aureus, Escherichia coli, Mycobacterium tuberculosis, Listeria spp., Brucella spp [13]. The presence of these pathogenic bacteria in milk emerged as major public health concerns, especially for those individuals who still drink raw milk [13].

The consumption of milk and milk products varies geographically between the highlands and the low lands and even in the level of urbanization. In the lowlands like Borena, one of the pastoralists group in Ethiopia, where livestock keeping is the main occupation, milk is consumed by all groups of the society. In Borana, pastoralists traditionally ferment cow milk and this product is called iti$t u$. It is considered as one of the special foods and served to many respected 
guests as well as to weaning-age children and the elderly. It is consumed as a side dish with traditional porridge or thin baked cereal bread [14]. During the traditional production of ititu, fresh milk is collected in a well-smoked fermenting vessel called Gorfa. It is prepared at $27^{\circ} \mathrm{C}-30^{\circ} \mathrm{C}$ for $15-30$ days with periodic removal of whey with wooden pipet (Dhumaa) \& the addition of fresh milk every 3 - 4 days, which needs a longer time of fermentation. The process of whey removal and addition of fresh milk is repeated several times until the product is concentrated enough and is ready for consumption [14].

However, there is limited work so far undertaken regarding ititu (traditionally fermented cow milk) and the recently available report also lacks bacteriological quality and physicochemical properties in particular to the Borana zone. Therefore, this work is aimed to evaluate physicochemical properties and microbiological qualities of traditionally fermented cow milk, ititu, in the selected districts of Borana Zone Oromia regional state, Ethiopia. The study also attempted to manufacture a prototype sample using the standard procedure of ititu in the laboratory for comparison of qualities.

\section{Materials and Methods}

\subsection{Study Area}

The study was conducted in Yabello, Arero and Dire districts of Borana zone, Oromia regional state, Ethiopia, focusing on pastoralists who own cow and produce cow milk in order to get background information regarding production practices of the traditional fermented cow milk ititu in the area. The districts were purposively selected based on potential of cow possessions and accessibility and willingness of the households to take part in the study. Yaballo is located at a distance of $563 \mathrm{~km}$ from Addis Ababa, the Capital city of Ethiopia. Arero and Dire are located at equidistant $(100 \mathrm{~km})$, each to east and south of Yabello town, respectively. Yabello is located at 1350 - 1800 meter above sea level (m.a.s.l.) and it is located between latitude $4^{\circ} 30^{\prime} 55.81^{\prime \prime}$ and $5^{\circ} 24^{\prime} 36.39^{\prime \prime} \mathrm{N}$ and longitude $7^{\circ} 44^{\prime} 14.70^{\prime \prime}$ and $38^{\circ} 36^{\prime} 05.35^{\prime \prime E}$. Borana rangeland is found in the south most part of Ethiopian lowlands occupying about 555,000 hectares total land area [15]. The mean annual rainfall is about $700 \mathrm{~mm}$ which is bimodal in distribution with $59 \%$ of total annual precipitation occurring from March to May and 27\% from September to November. The mean monthly maximum and minimum temperature is $19^{\circ} \mathrm{C}$ and $24^{\circ} \mathrm{C}$, respectively [16].

\subsection{Traditional ititu Making Procedure}

According to respondents, ititu is made from cow milk by natural spontaneous fermentation without addition of any starter culture. Some respondents suggested that, it is also made from goat milk but it has no consistency like that of ititu made from cow milk. Souring of milk is practiced at any time when surplus milk is available and mainly during wet season. The complete process of fermentation takes place for 15 days but for immature ititu, which is locally called 
"Kelba", the process of fermentation is only about 2 - 3 days. The study shows that the storage utensil used for preparation of ititu is called Gorfa (made from root fiber of some plants) and it is also used for churning of milk for butter production in the study area. Almost all respondents followed the same procedure for making ititu in the study area. According to the interviewed households, the procedure for making was: first the Gorfa is washed with water and mainly smoked with Olea africana (Ejersa), Terminallia brownii (Bireessa), Daansee, Acacia nilotica (Burquqqee) Maerua triphylla (Dhumasoo) and Combretumhereroense Schinz (Kennoo) were common Then the fresh raw milk is filled and tightly closing the Gorfa and hanging it in the Sepana (a part of the house in which some tool is hanging on it). The milk becomes traditionally fermented after 3 - 4 days and more than 4 days in Gorfa under room temperature. Whey liquid (Dhama) is removed from the container by wooden pipette after which fresh milk is added and the removed "Dhama” was usually drunk by group of people in the village. Further incubation of fermented milk for about 3 - 4 days forms "Kelba (immature ititu)" which is not hard and lacks consistency The removal of the whey liquid (Dhama) from fermented milk is more practiced within 3 - 4 days of interval and followed by addition of the fresh milk to fill Gorfa. This process continuous until the Gorfa is filled with hard curd). The result of survey indicated that, to obtain the hard card which is ititu it takes about 15 days.

\section{3. ititu Sample Collection and Transportation}

A total of thirty-five ititu samples of fifteen days old ititu were collected from the pastoral households and laboratory-made to investigate the physicochemical properties and microbial quality of ititu. Thirty ititu samples from pastoral households and five ititu samples from laboratory-made were collected. ititu samples were prepared in the laboratory by simulating the traditional methods except for Pasteurization of raw milk and the addition of stature culture for fermentation (acidification). A total of five raw cow milk samples were collected from Yabello Research Pastoral and Dry Land Agricultural Research Center's (YPDARC) dairy farm with proper hygiene from milking up to arrival to a laboratory of YPDARC for laboratory-made ititu. During collection, approximately $250 \mathrm{ml}$ ititu sample was taken from the container into sterile glass bottles. The milk samples taken from the different containers at a market (from the sellers) were pooled in sterilized containers and thoroughly mixed and then, placed into sterile glass bottles. Then the samples were labeled and transported in icebox the same day to the Dairy Laboratory of Hawassa University where its physicochemical properties and microbial quality were analyzed.

\subsection{Physicochemical Analysis}

\subsubsection{Titratable Acidity Test}

Titratable acidity (TA) of the ititu samples was determined according to the method of the Association of Official Analytical Chemists [17]. Nine ml of ititu 
sample was pipetted into a beaker and 3 to 5 drops of $1 \%$ phenolphthalein indicator was added to it. The sample then titrated with $0.1 \mathrm{~N} \mathrm{NaOH}$ solution until a faint pink color persisted. The titratable acidity expressed as \% lactic acid, was finally calculated using the following formula.

$$
\mathrm{TA} \%=\frac{\mathrm{N} / 10 \mathrm{NaoH}(\mathrm{ml}) \times(0.09)}{\text { Weight of sampple }} \times 100
$$

\subsection{2. $\mathrm{pH}$ Determination}

The $\mathrm{pH}$ of the ititu samples was determined in the laboratory using a digital $\mathrm{pH}$-meter based on the procedure described by O'Connor (1995). The $\mathrm{pH}$ meter was calibrated using buffers of $\mathrm{pH} 7.0$ and 4.0 each time before the $\mathrm{pH}$ of ititu samples was measured. $\mathrm{pH}$ was measured by dipping the electrode of the $\mathrm{pH}$ meter into each representative sample $(250 \mathrm{ml})$ upon arrival of the samples at a laboratory. Cleaning of the tip of the electrode with distilled water was employed between the testing of each sample.

\subsubsection{Total Solids (TS)}

The total solids content of the ititu was determined by oven drying at $105^{\circ} \mathrm{C}$ overnight. Moisture and the total solid content were determined according to [18] methods. About $5 \mathrm{~g}$ of sample was weighed into a dry and pre-weighed crucible and the samples were labeled carefully using a pencil. The crucible and its content was then transferred into the oven at a temperature of $105^{\circ} \mathrm{C}$ and dried for $12 \mathrm{~h}$. The crucibles were allowed to cool in desiccators and weighed. The crucibles were returned into the oven for another half hour and again cooled and reweighed. The process was repeated until a constant weight was reached. The total solids content was calculated according to the following formula:

$$
\text { TS }=\frac{\text { weight sample Cwt }- \text { weight sample dry Oven }}{\text { crucible weight }} \times 100
$$

were, Cwt $=$ crucible weight

\subsubsection{Crude Protein Determination}

The total protein content of the ititu samples was determined by the Kjeldahl method [17] according to the following procedures: For digestion: Five grams of ititu samples were warmed in a water bath at $38^{\circ} \mathrm{C}$ and poured into a Kjeldahl flask. Fifteen-gram potassium sulfate, $1.0 \mathrm{ml}$ of copper sulfate solution and $25 \mathrm{ml}$ of concentrated sulphuric acid was added into the flask and mixed gently. The digestion was carried out in a digestion block until a clear solution appeared. Then it was allowed to cool to room temperature. For distillation: The digestion flask was placed in the distillation equipment and then $30 \mathrm{ml}$ of distilled water and $75 \mathrm{ml}$ of $50 \%$ sodium hydroxide solution were added into it. Then, ammonia was distilled then $50 \mathrm{ml}$ of $40 \%$ boric acid solution using bromocresol green indicator was added until the blue color appeared. Finally, the sample was titrated with $0.1 \mathrm{~N}$ hydrochloric acid solution from a burette until a faint pink 
color solution was formed and the burette reading was taken to the nearest 0.01 $\mathrm{ml}$. The blank test was carried out using the above procedure except that water was used instead of a test sample. The percentage of nitrogen in the samples was calculated as follows:

$$
\% \mathrm{~N}=\frac{(\mathrm{Vb}-\mathrm{Vs}) \mathrm{HCl} \text { consumed } \times \mathrm{NHCl} \times 1.4007}{\text { Sample weight }} \times 100
$$

$\% \mathrm{CP}=\% \mathrm{~N} \times 6.38$ where,

$\% \mathrm{~N}=$ percentage nitrogen by weight;

$\mathrm{Vs}=$ volume of $\mathrm{HCl}$ used for titration of sample;

$\mathrm{Vb}=$ volume of $\mathrm{HCl}$ used for titration of the blank;

$\% \mathrm{CP}=$ percentage of crude protein.

\subsubsection{Fat Content}

The fat content of ititu was determined according to the Official Methods of Analysis [18]. Thus $10 \mathrm{ml}$ sulphuric acid was added into the butyrometer (8 calibrations) followed by $11 \mathrm{ml}$ of well-mixed samples for whey and ititu. Three grams $(3 \mathrm{~g})$ of ititu sample was added with $8 \mathrm{ml}$ water. Then $1 \mathrm{ml}$ of Amyl alcohol was added and immediately insert stopper and shake the butyrometer carefully until the curd dissolves and no white particles can be seen. The butyrometer was kept in the water bath at $65^{\circ} \mathrm{C}$ until a set was ready for centrifuging. Finally, the butyrometer was placed in the centrifuge for 5 minutes and kept in the water bath at $65^{\circ} \mathrm{C}$ for the other 5 minutes to be settled and ready for reading.

\subsubsection{Ash Content}

The ash content ititu was determined by incinerating $5 \mathrm{~g}$ in a muffle furnace at $550^{\circ} \mathrm{C}$ for $6 \mathrm{~h}$. After cooling in desiccators for a period of 45 minutes, the $\%$ of total ash content was calculated on a dry basis according to Official Methods of Analysis [18].

$$
\text { Ash }=\frac{\text { weight Residue }}{\text { weight Sample weight Residue }} \times 100
$$

\subsection{Microbiological Quality Analysis}

\subsubsection{Total Plate Count}

For total plate count, appropriate decimal dilutions were prepared that result in a total number of colonies on a plate between 30 and 300 [19]. A standard Plate Count Agar (PCA) (Oxoid, CM0325: UK) was first sterilized according to the manufacturer's instructions and then it was cooled to $45^{\circ} \mathrm{C}$ before pouring. One $\mathrm{ml}$ of ititu sample was added into a sterile test tube containing nine $\mathrm{ml}$ of peptone water (15\%) and was mixed thoroughly. Then one $\mathrm{ml}$ of the sample from appropriate decimal dilution was placed on duplicate Petri dishes and then about $15 \mathrm{ml}$ of the molten agar was added to it and mixed thoroughly. The plates were incubated for 48 hours at $32^{\circ} \mathrm{C}$ [19]. Finally, colony count was made using a colony counter (RDC, M671: England). The estimated number of colonies per 
$\mathrm{ml}$ of the sample was calculated by the formula.

$$
\mathrm{N}=\frac{\sum \mathrm{CN}}{(1 \times n 1)+(0.1 \times n 2)} \times d
$$

where,

$$
\begin{aligned}
& \mathrm{N}=\text { Number of colonies per ml of milk sample } \\
& \Sigma \mathrm{C}=\text { Sum of all colonies on plates counted } \\
& n 1=\text { Number of plates used in lowest dilution counted } \\
& n 2=\text { Number of plates used in highest dilution counted } \\
& d=\text { dilution factor of the lowest dilution used. }
\end{aligned}
$$

\subsubsection{Coliform Count (CC)}

One $\mathrm{ml}$ of ititu sample was dispensed into sterile test tubes containing $9 \mathrm{ml}$ of $0.1 \%$ peptone water and thoroughly mixed using whirl mixer. Subsequent serial decimal dilutions were prepared in a similar manner using $0.1 \%$ peptone water. Duplicate appropriate decimal dilutions were surface plated on Violet Red Bile Agar (VRBA) and incubated at $45^{\circ} \mathrm{C}$ for 24 hours. After complete incubations, typically dark red colonies on uncrowned plates were considered as coliforms for colony counts. This was followed by a confirmatory test by transferring five colonies from each plate to tubes of $2 \%$ Brilliant Green Lactose Bile Broth (BGLBB). Gas production after $24 \mathrm{~h}$ of incubation at $32^{\circ} \mathrm{C}$ was considered sufficient evidence of the presence of coliforms [19].

\subsubsection{Yeast and Mould Count (YMC)}

For yeast and mould count, ititu samples were serially diluted in peptone water and volumes of $1 \mathrm{ml}$ of appropriate dilutions were plated in duplicate Petri dishes by the pour plate technique using Potato Dextrose Agar (PDA) (Oxoid, Pvt. Ltd. MU 096: Uk). Colonies were counted after incubation at $25^{\circ} \mathrm{C}$ for 5 days [19]. The number of microorganisms or colony-forming units (CFU) per milliliter of ititu samples was calculated as indicated for the total plate count above.

\section{1) Staphylococcus aureus}

Presumptive colonies of Staphylococcus aureus were selected and subcultured on nutrient agar and incubated aerobically at $37^{\circ} \mathrm{C}$ for $24-48 \mathrm{~h}$. After this incubation on nutrient agar, bacteria were identified according to their Gram reaction, morphology and the catalase test. $S$. aureus was identified by the tube coagulase test $(4 \mathrm{~h})$, hemolysis (blood sheep as substrate), pigment production (golden yellow), mannitol and maltose fermentation. Samples were considered as positive for S. aureus when at least one colony was identified as $S$. aureus.

\section{2) Listeria monocytogenes}

For the detection of Listeria monocytogenes, well-mixed testing samples (25 $\mathrm{ml}$ ) were homogenized in $225 \mathrm{ml}$ of Listeria Enrichment Broth A and B and incubated for $24 \mathrm{~h}$ at $37^{\circ} \mathrm{C}$ [20]. A loop full of the enrichment culture broth was streaked in duplicate onto Polymyxin-Acriflavin-Lithium Chloride-CeftazidimeAesculin-Mannitol (PALCAM) agar and incubated for $48 \mathrm{~h}$ at $37^{\circ} \mathrm{C}$. Suspected 
Listeria monocytogenes colonies were further characterized using staining, catalase reaction, umbrella-shaped motility pattern, hemolysis on sheep blood agar, fermentation of mannitol, rhamnose, xylose, glucose and maltose, and Acronym for Christie Atkins, Munch, Petersent (cAMP) tests, in accordance with Bergey's Manual of Systematic Bacteriology.

\subsection{Data Analysis}

The results of physicochemical and microbial counts were first transformed to logarithmic values $(\log 10)$ and these transformed values were analyzed using the General Linear Model (GLM) for least squares means in SAS 9.1 (SAS, 2009) using a fixed-effect model. The Least Significant Difference (LSD) test was used to separate the means and differences were considered significant at $\mathrm{P}<0.05$.

The following model was used for the analysis of physicochemical and microbial test of ititu;

$$
Y_{i j}=\mu+\beta_{i}+E_{i j}
$$

$Y_{i j}=$ Individual observations for bacteriological quality and physicochemical properties of ititu (dependent Variable);

$\mu=$ Overall mean;

$\beta_{i}=$ ititu manufacturing types effect;

$E_{i j}=$ Random error

\section{Result and Discussion}

\subsection{Physicochemical Properties of ititu}

Traditionally made and laboratory-made ititu (control) were analyzed for physicochemical properties (Table 1). There was no significant difference observed between the traditional and laboratory-made ititu for all physicochemical analyses. The average $\mathrm{pH}$ values were $3.59 \pm 0.04$ and $3.55 \pm 0.34$ traditional and laboratory-made ititu, respectively.

Table 1. Physicochemical parameters, $\mathrm{pH}$ and acidity of traditional and laboratory-made ititu in the study area.

\begin{tabular}{ccc}
\hline Variables & Traditional ititu & Laboratory made ititu \\
\hline Total Solid (\%) & $21.23 \pm 1.48$ & $21.58 \pm 0.67$ \\
Fat (\%) & $9.85 \pm 0.73$ & $10.12 \pm 0.62$ \\
Protein (\%) & $7.26 \pm 0.41$ & $7.31 \pm 0.03$ \\
Ash (\%) & $0.84 \pm 0.11$ & $0.88 \pm 0.18$ \\
pH & $3.59 \pm 0.04$ & $3.55 \pm 0.34$ \\
Titratable Acidity (\%) & $2.86 \pm 0.18$ & $2.92 \pm 0.2$
\end{tabular}

Values in the table are means \pm SD of two replications; Values with the same letters in the raw are not statistically significant difference $(\mathrm{P}>0.05)$. 
The average total solid of traditional and laboratory-made ititu was $21.23 \% \pm$ $1.48 \%$ and $21.58 \% \pm 0.67 \%$, respectively (Table 1 ). There was no significant difference $(\mathrm{P}>0.05)$ between traditional and laboratory-made ititu in total solid percentage. The higher total solid in the current study for both traditional and laboratory-made ititu was due to the addition of fresh milk at every time of removing the whey liquid during the manufacturing of ititu.

The highest value of fat percentage in both traditional and laboratory-made ititu in the current study was due to the difference in manufacturing procedure that continues the concentration of ititu was made by removing the whey component that comes due to syneresis.

\subsection{Microbial Counts of Traditional and Laboratory Made ititu}

\subsubsection{Total Bacteria Count (TBC)}

The overall total bacterial counts (TBC) of traditional and laboratory-made ititu were $8.36 \pm 1.29$ and $4.17 \pm 0.55 \log _{10} \mathrm{cfu} / \mathrm{ml}$, respectively (Table 2 ). The present result shows that there was a significance difference $(\mathrm{P}<0.05)$ between traditional and laboratory ititu (Table 2). The present study also showed that the highest result of TBC was recorded in traditionally made ititu while the least was in laboratory-made ititu (Table 2). This difference was due to hygienic practice followed during milking and Pasteurization of laboratory-made ititu. The value of TBC for traditional ititu exceeds the acceptable limits of unpasteurized milk and milk product $\left(\leq 10^{5} \mathrm{cfu} / \mathrm{ml}\right)$ while the value of laboratory-made ititu was below acceptable limits of pasteurized milk and milk product (below $2 \times 10^{4} \mathrm{cfu} / \mathrm{ml}$ ) [21] which was safe for consumption. This was due to hygienic practices followed during all manufacturing steps and pasteurization of laboratory-made ititu.

\subsubsection{Coliform Count (CC)}

The mean coliform count (CC) of traditionally made ititu was $3.47 \pm 0.51$ $\log _{10} \mathrm{cfu} / \mathrm{ml}$; while no CC was detected for laboratory-made ititu (Table 2). There was significance $(\mathrm{P}<0.05)$ of mean count for $\mathrm{CC}$ between laboratory and traditional made ititu (Table 2). The highest value of CC was detected in traditional while not detected in laboratory-made ititu (Table 2). The significance

Table 2. Mean microbial counts $\left(\log _{10} \mathrm{CFU} / \mathrm{mL}\right)$ of traditionally and laboratory-made ititu samples in the study area.

\begin{tabular}{ccc}
\hline Microbial counts & Traditional ititu & Laboratory made ititu \\
\hline Total bacteria (TBC) & $8.36 \pm 1.29^{\mathrm{a}}$ & $4.17^{\mathrm{b}} \pm 0.55$ \\
Coliform (CC) & $3.47 \pm 0.51^{\mathrm{a}}$ & $\mathrm{ND}$ \\
Yeast and mold (YMC) & $8.06 \pm 1.28^{\mathrm{a}}$ & $5.76 \pm 0.57^{\mathrm{b}}$ \\
Staphylococcus aureus & $3.79 \pm 0.91^{\mathrm{a}}$ & $\mathrm{ND}$ \\
Listeria monocytogenes & $3.15 \pm 0.17^{\mathrm{a}}$ & $\mathrm{ND}$ \\
\hline
\end{tabular}

Superscripts in the same raw having different letters indicate a significant difference $(\mathrm{P}<0.05)$ among the ititu samples; values in the table are means \pm SD of two replications. ND= Not detected. 
Difference $(\mathrm{P}<0.05)$ between traditional and laboratory-made ititu samples might be due to the existence of coliform bacteria in milk and milk products which is an indicator of fecal contamination and unsanitary practices during production, processing, or storage for traditionally made ititu. The result of the present study for coliform counts of traditional ititu exceeds the acceptable limits of raw milk and milk product which was below $\leq 100 \mathrm{cfu} / \mathrm{ml}$. This implies the traditional ititu was not safe for consumption while vice versa for laboratory-made ititu.

\subsubsection{Yeast and Mould Count (YMC)}

The mean yeast and mould count (YMC) of traditional and laboratory-made ititu were $8.06 \pm 1.28$ and $5.76 \pm 0.57 \log _{10} \mathrm{cfu} / \mathrm{ml}$ (Table 2), respectively. There was a significant $(\mathrm{P}<0.05)$ difference between traditional and laboratory-made ititu for YMC. Traditional ititu had the highest YMC and the least record was in laboratory-made ititu samples (Table 2). The higher YMC observed in traditional ititu might be attributed to contamination from the air, storage temperature, humidity, the containers or poor hygienic conditions followed by the producers and poor personal hygiene of individuals. The values for both traditional and laboratory-made ititu were much higher than the acceptable value $(<10$ $\mathrm{cfu} / \mathrm{gm})[22]$.

\section{1) Staphylococcus aureus}

The mean count of $S$. aureus of traditionally made ititu was $3.79 \pm 0.91$ $\log _{10} \mathrm{cfu} / \mathrm{ml}$, while was not detected in the laboratory made ititu (Table 2). The average counts of $S$. aureus of traditionally made ititu were significantly different $(\mathrm{P}<0.05)$ between traditional and laboratory-made ititu for the present study (Table 2). The highest value for $S$. aureus count was detected in the traditional ititu while not detected laboratory-made ititu (Table 2). This might be due to pasteurization of raw milk and hygienic condition followed during milking production of laboratory-made ititu. The value of $S$. aureus for traditional ititu was higher than the acceptable values in which pathogenic microorganisms should not be detected in $9 \mathrm{ml}$ of the product [23].

\section{2) Listeria monocytogenes}

The overall mean of Listeria monocytogenes count for traditional and laboratory-made ititu was $3.15 \pm 0.17 \log _{10} \mathrm{cfu} / \mathrm{ml}$ and not detected (Table 2) respectively. There was a significant difference $(\mathrm{P}<0.05)$ between the traditional and laboratory-made ititu. The difference was due to proper hygiene during milking up to the production of ititu and Pasteurization of raw milk that used for laboratory-made ititu. The value of Listeria monocytogenes for traditional ititu was higher than the acceptable values in which pathogenic microorganisms should not be detected in $25 \mathrm{ml}$ of the product [23].

\subsubsection{Prevalence of Some Pathogenic Microorganisms}

\section{1) Staphylococcus aureus}

The overall prevalence of $S$. aureus for traditional and laboratory-made ititu sample was $33.33 \%(10 / 30)$ and $0 \%$ respectively (Table 3 ). This attributed to 
Table 3. Prevalence of Staphylococcus aureus and Listeria monocytogenes of traditional and laboratory-made ititu in the study area.

\begin{tabular}{cccc}
\hline \multirow{2}{*}{ ititu types } & $\begin{array}{c}\text { Number of collected } \\
\text { samples }\end{array}$ & \multicolumn{2}{c}{ Number of positive samples (n) (\%) } \\
\cline { 3 - 4 } & 30 & $\begin{array}{c}\text { Staphylococcus } \\
\text { aureus }\end{array}$ & $\begin{array}{c}\text { Listeria } \\
\text { monocytogenes }\end{array}$ \\
\hline Traditional ititu & 5 & $10(33.33)$ & $2(6.67)$ \\
Laboratory made ititu & & $0(0)$ & $0(0)$
\end{tabular}

poor in pre-milking washing udder, washing milking utensils with boiled water and quality water used for cleaning utensils in traditional fermented ititu. It also due to the fact that $S$. aureus appears in milk from cows affected with mastitis [24].

\section{2) Listeria monocytogenes}

In the present study of the 30 examined traditional made ititu samples, 2 (6.67\%) were positive for the presence of Listeria monocytogenes, while no detected in laboratory-made ititu (Table 3). Higher prevalence Listeria monocytogenes was detected in traditional ititu.

\section{Conclusions}

The result of all physicochemical parameters of traditional ititu was not significantly) different $(\mathrm{P}>0.05)$ with laboratory-made ititu (control sample). ititu manufacturing was able to concentrate/increases the initial milk's total solid nearly by two folds that will be a significant improvement of food from a nutritional point of view. The result of microbial quality showed that traditional production of ititu in the study area was not hygienic and safe for consumption while laboratory-made ititu was safe for consumption. In addition there is no significant difference $(\mathrm{P}>0.5)$ among the three districts (which are traditional ititu) in terms of physicochemical parameters and microbial analysis. These results appear to suggest the following recommendation:

- The present study revealed that ititu made traditionally by pastoralists was found to be poor in quality and this was attributed to the poor hygienic conditions followed during handling and preparation of ititu. This calls the need for awareness creation and training of pastoralists to follow proper hygienic practices during milking and production of ititu and heating up to boiling of raw milk before used it to make ititu.

- The adoption of physicochemical properties of whey part of ititu, will need further study in the future.

- In the present study, lactic acid bacteria (LAB) responsible for the fermentation of cow milk and the production of ititu, not studied. Thus, identification and isolation of $\mathrm{LAB}$ responsible for ititu production deserves detailed study in the future

- In the present study, some pathogenic microorganisms like E. coli, Tubercu- 
losis and Salmonella spp. were also not examined in the ititu production. So this calls for detailed study in the future.

\section{Acknowledgements}

The authors are grateful to Oromia Agricultural Research Institute (OARI) for financing this research project. Yabello Pastoral and Dryland Agriculture Research Center is highly appreciated for providing facilities to conduct the research.

\section{Abbreviations}

"BGLBB" means "Brilliant Green Lactose Bile Broth", "BPDO" means "Borana Zone Agricultural and Pastoral Development Office", "cAMP" means "Cyclic Adenocyne Monophosphate", "CC" means "Coliform Count", "Cfu" means "Colony Forming Unit", "EADD" means "East Africa Dairy Development", "EMB" means "Eosin Methylene Blue", "FA" means "Food and Agricultural Organization of United Nation", "FCT" means "Federal Capital Territory", "GLM" means "General Linear Model", "IDF" means "International Dairy Federation", "ILCA" means "International Livestock Center for Africa", "ILRI" means "International Livestock Research Institute", "LEB" means "Listeria Enrichment Broth", "LMP" means "Livestock Master Plan", "MFB" means "Modified Fraser Broth", "MOA" means "Ministry of Agriculture", "OARI" means "Oromia Agricultural Research Institute", "PDA" means "Potato Dextrose Agar", "TBC" means "Total Bacterial Count", "VRLBA" means "Volatile Red Bile Agar", "YMC" means "Yeast and Mold Count", and "YPDARC" means Yabello Pastoral and Dryland Agriculture Research Center.

\section{Conflicts of Interest}

The authors declare no conflicts of interest regarding the publication of this paper.

\section{References}

[1] Gebrewold, A., Mengistu, A., Deneke, S., Dediye, S. and Tadesse, A. (2000) Status of Dairy Research in Ethiopia. The Role of Village Dairy Co-Operatives in Dairy Development: Small Holder Dairy Development Project (SDDP). Proceeding of Ministry of Agriculture (MOA), Addis Ababa, Ethiopia, 2000.

[2] Ayenew, Y.A., Wurzinger, M., Tagegn, A. and Zollitsch, W. (2009) Performance and Limitation of Two Dairy Production System in the North Western Ethiopian Highlands. Tropical Animal Health Production, 41, Article No. 1143. https://doi.org/10.1007/s11250-008-9294-3

[3] Olatunji, E.A., Jubril, A.E., Okpu, E.O., Olafadehan, O.A., Ijah, U.J. and Njidda, A.A. (2012) Bacterial Assessment and Quality Analysis of Raw Milk Sold in Gwagwalada Area Council of the Federal Capital Territory (FCT) Abuja, Nigeria. Food Science and Quality Manage, 7.

[4] Tsehay, R. (2001) Small-Scale Milk Marketing and Processing in Ethiopia. Proceedings of the South Workshop on Smallholder Dairy Production and Marketing Con 
straints and Opportunities, Addis Ababa, Ethiopia, March 2001, 13-16.

[5] Mekasha, Y., Tagegn, A., Yami, A. and Umunna, N.N. (2003) Evaluation of the General Farm Characteristics and Dairy Herd Structure in Urban and Peri-Urban Dairy Production Systems in Addis Ababa Milk Shed.

[6] Zegeye, Y. (2003) Challenges and Opportunities of Livestock Marketing in Ethiopia. Proceeding of the 10 th Annual Conference of Ethiopian Society of Animal Production (ESAP), Addis Ababa, Ethiopia, 22-24 August 2002, 47-54.

[7] Tadesse, D., Ayalew, W. and Hegde, B.P (2005) Survey of Traditional Cattle Production Systems and Preferred Cattle Functions in North and South Wollo Zones, Ethiopia. Ethiopian Veterinary Journal, 9, 91-108.

[8] Yilma, Z., Guernebleich, E. and Sebsibe, A. (2011) Review of the Ethiopian Dairy Sector. Food Agricultural Organization (FAO) Sub Regional Office for Eastern Africa (FAO/SFE), Addis Ababa, 81.

[9] Agza, B., Melesse, K., Funga, A. and Melesse, K. (2013) Assessment of Knowledge Gap and Factors Affecting the Consumption of Dairy Products in Ada'a and Lume Districts of East Showa Zone, Ethiopia. African Journal of Food Science and Technology, 4, 201-210.

[10] Hemme, T. and Otte, J. (2011) Status and Prospects for Smallholder Milk Production: A Global Perspective. Food and Agriculture Organization of the United Nations (FAO), Rome.

[11] Al-Otaibi, M.M. (2009) Evaluation of Some Probiotic Fermented Milk Products from Al-Ahsa Markets, Saudi Arabia. American Journal of Food Technology, 4, 1-8. https://doi.org/10.3923/ajft.2009.1.8

[12] Uccello, M., Malaguarnera, G., Basile, F., D’agata, V., Malaguarnera, M., Bertino, G. Vacante, M., Drago, F. and Biondi, A. (2012) Potential Role of Probiotics on Colorectal Cancer Prevention. BMC Surgery, 12, Article No. 35.

https://doi.org/10.1186/1471-2482-12-S1-S35

[13] Lingathurai, S. and Vellathurai, P. (2010) Bacteriological Quality and Safety of Raw Cow Milk In Madurai, South India. Webmed Centeraln Microbiology, 1, Article ID: WMC001029.

[14] Gonfa, A., Foster, H.A. and Holzapfel, W.H. (2001) Field Survey and Literature Review on Traditional Fermented Milk Products of Ethiopia. International Journal of Food Microbiology, 68, 173-186. https://doi.org/10.1016/S0168-1605(01)00492-5

[15] Borana Zone Agricultural and Pastoral Development Office (BPDO) (2008) Yabello , Ethiopia

[16] Coppock, D.L. (1994) The Borana Plateau of Southern Ethiopia: Synthesis of Pastoral Research, Development, and Changes 1980-91. International Livestock Center for Africa, Addis Ababa, Ethiopia.

[17] Association of Official Analytical Chemists (AOAC) (1990) Association of Official Analytical Chemist. 15th Edition, Official Methods of Analysis, Washington DC.

[18] Association of Official Analytical Chemists (AOAC) (2005) Method 935.14 and 992.24. 18th Edition, Association of Officiating Analytical Chemists, Washington DC.

[19] Richardson GH (1985) Standard Methods for the Analysis of Dairy Products.

[20] Yousef, A.E. and Carlstrom, C. (2003) Food Microbiology: A Laboratory Manual. John Weiley and Son, Inc., Hoboken, New Jersey, Canada, 288 p.

[21] United States Public Health Service (1995) Grade A Pasteurized Milk Ordinance. Food and Drug Administration, Washington DC, No. 229. 
[22] Mostert, J.F. and Jooste, P.J. (2002) Quality Control in the Dairy Industry. In: Robinson, R.K., Ed., Dairy Microbiology Handbook, 3rd Edition, John Wiley, New York, 655-736. https://doi.org/10.1002/0471723959.ch14

[23] Council Directives 92/46 EEC (1992) Laying down the Health Rules for the Production and Placing on the Market of Raw Milk, Heat-Treated Milk and Milk-Based Products. Official Journal of the European Communities, No L 268/1.

[24] Al-Tahiri, R. (2005) A Comparison of Microbial Conditions between Traditional Dairy Products Sold in Karak and Same Products Produced by Modern Dairies. Pakistan Journal of Nutrition, 4, 345-348. https://doi.org/10.3923/pjn.2005.345.348 